https://doi.org/10.18485/iipe_ru_sr.2020.ch2

\title{
BALKAN VECTOR OF RUSSIAN FOREIGN (PUBLIC) POLICY: THE EXAMPLE OF SERBIA ${ }^{1}$
}

\author{
Miroslav Mladenović \\ Elena Georgievna Ponomareva ${ }^{2}$
}

Abstract: Neither in the current nor the previous concepts of the foreign policy of the Russian Federation, there are no specific provisions related to the countries of the Balkans, including Serbia.

In terms of regional priorities, the focus is on the CIS and Eurasian integration; India and the People's Republic of China particularly stand out.

Judging by official documents and concepts, Russia has no special interest in the countries of the Balkan region. Although this statement is obvious, the conclusion that the area of the Balkans, including Serbia, is out of the real focus of the foreign policy of the Russian Federation would certainly be incorrect.

In addition to the official, there is also an unofficial component of the political activity of each country, and in addition to state, there is also an extensive system of non-state, i.e., public policy and diplomacy. There is a reminder here of De Gaulle's famous remark that "Politics is too serious a matter to be left to politicians".

Public diplomacy, however, should not be understood as a self-contained sphere of activity independent of the state. Every authority wants to create a

\footnotetext{
${ }^{1}$ A broader version of the role of Russian "soft power" in the Balkans: Елена Пономарева, Мирослав Младенович, Публичная дипломатия России: балканское направление, Международная жизнь апрель 2016, Москва, ISSN 0130-9625, стр. 151-166;

${ }^{2}$ Dr. Miroslav Mladenović, full-time professor at the Faculty of Security Studies of the University of Belgrade, e-mail: m.mladenovic@fb.bg.ac.rs

Dr. Elena Georgievna Ponomareva, full-time professor of the MGIMO University of the Russian Federation, e-mail: nastya304@mail.ru
} 
favourable image for itself, which facilitates solving many economic and geopolitical tasks. In this sense, Russia is no exception. A more serious approach to the problem of public diplomacy by the Russian state has been evident since the third presidential term of V. Putin, that is, from the second decade of the 21st century. In this paper, the focus will be on the less visible levers of Russian foreign policy towards the Balkan region, and above all in relation to Serbia.

Keywords: Serbia, Russia, public diplomacy, soft power, foreign policy.

\section{Public diplomacy}

In the conditions of global (political, economic, information and other) transformations, public diplomacy, as one of the most efficient foreign policy practices, has an increasingly important place. Under the impressive development of technical and information sciences and policies, both external and internal policy inevitably becomes more transparent and increasingly accessible to non-state and non-traditional actors.

"Four centuries ago, Niccolo Machiavelli advised the rulers in Italy that it was more important they were feared rather than loved. But in today's world, it is best if you can do both. Winning hearts and minds has always been important, but it is of particular importance in the global information age. Information is power, and modern information technology spreads information much wider than ever before in history. However, political leaders have taken very little time to understand how the nature of power has changed, and have paid particularly little attention to ways of incorporating soft aspects into their strategies for gaining power".

In order for these observations of Joseph Nye to be realized, it is necessary to include network and information components in the system of foreign policy. The main elements of that complex are not only politicians and other state subjects but also the media, non-governmental organizations, scientific and educational institutions, bearers of culture and sports, and users of social networks. Paraphrasing the words of Charles de Gaulle, we can say: "Politics is too serious a matter to be left to politicians".

${ }^{3}$ Joseph Nye, Soft Power, Public Affairs, New York, 2004, p. 1. 
However, it would be wrong to understand public diplomacy as a completely independent sphere of activity, separate from the state. Every country is very interested in creating a favourable image of itself. It is a precondition for solving the main political, economic, and other tasks and the realization of state interests.

In this sense, Russia is no exception. The decree of the President of Russia of May 7, 2012, "On measures for the implementation of the foreign policy course of the Russian Federation", especially emphasizes the interest of the state in improving the efficiency of foreign policy in the new conditions. ${ }^{4}$

The document points to the need for the state to "use the resource of public diplomacy more efficiently, involve civil society in the foreign policy process, strengthen interaction with the Chamber of Commerce of the Russian Federation, the non-profit organization "Fund for Support of Public Diplomacy AM Gorchakov" and other non-governmental organizations, and to cooperate with them during their wide participation in the activities of world forums of expert-political dialogue and international humanitarian cooperation".

Although especially, in the beginning, public diplomacy was understood not only, and not so much, as a state but as a public phenomenon, it was and has remained, an important implementer of the national interests of a certain country. Therefore, the deeper meaning of public diplomacy is the creation of a special synergy of government and social initiatives.

The main difference in the essential meaning of classical and public diplomacy, therefore, is not their goal. It is common for both of these activities. The difference is in the subject who realizes those goals. In public diplomacy, the state is not the main bearer of activities, but "the impetuous part of society, including every citizen who is not indifferent to what and how is happening in Russia and abroad".

\footnotetext{
${ }^{4}$ Указ Президента РФ от 7 мая 2012 г. «0 мерах по реализации внешнеполитического курса Российской Федерации» // URL: http:// www.kremlin.ru/events/president/news/15256, (seen 04.09.2020)

${ }^{5}$ Фонд поддержки публичной дипломатии им. А.М.Горчакова // URL: http://gorchakovfund.ru/about/,(seen 06.09.2020)
} 


\section{"Soft power" as an element of public diplomacy}

It is interesting to note that in the United States, the term "soft power" was coined in academia and then purposefully introduced into the political traffic at a high level.

In contrast, in Russia, the path of "enthronement of soft power" was the opposite. The idea of the need and possibility of applying the instruments of "soft power" came from political leaders, and then it was accepted by members of the academic community.

Perhaps this difference and the fact that the theory and practice overlap much more directly in the West than in the East is also essential to the realization of accepted ideas.

As it is known, the custom of transition from science to politics, from politics to intelligence institutions, from intelligence bureaus to science, etc. - is widely present in the West. The goal of such actions is - the widest possible placement and realization of the interests of a certain elite group. In particular, Dr. Nye's theoretical achievements have a clear practical significance, i.e., they are aimed at securing and spreading, as much as possible, of the dominant influence of the West, primarily the United States, on all major processes in the world.

In the Bill Clinton Administration, Nye was the Assistant Secretary of Defence for International Security Affairs in the Pentagon; in the period 1993-1994, he was the Head of the National Intelligence Council of the United States. In addition, he was a member of the Executive Committee of the Three Member Committee, which meets periodically in the Council on Foreign Relations. Moreover, Professor Nye managed the EastWest Institute for Security Research and the International Institute for Strategic Research. After Obama had become the head of state, he was involved in the work of the Center for the New American Security and the Project for the Reform of the National Security of the USA. ${ }^{6}$

As for Russia's "soft power", before it entered into the fundamental state foreign policy documents, it was promoted in the speeches of the representatives of the Russian government.

\footnotetext{
${ }^{6}$ See more in: Мирослав Младеновић, Јелена Пономарева, Теорија и пракса "шарених револуција", Социолошки преглед, Београд, RS ISSN 0085-6320, UDK 316, 2012, вол. 46, бр. 4, стр. 513-533;
} 
On the eve of the Moscow Conference of Compatriots Living Abroad, the Minister of Foreign Affairs of the Russian Federation, Sergei Lavrov, gave an interview to the Rossiyskaya Gazeta newspaper. In that interview, among other things, he pointed out that: "In modern conditions, the so-called soft power is gaining in importance. It is the ability to influence the surrounding world with the help of its own civilizational, humanitarian-cultural, foreign policy, and other attractions. It seems that the spectrum of our diverse ties with compatriots should be built with respect for these factors".

A slightly more detailed elaboration of the term "soft power" appeared on the pages of the newspaper Moscow News from February 27, 2012, in article V. Putin, entitled "Russia and the changing world." Along with the thesis on the effectiveness of "soft power" in the foreign policy of the globalization era, the author also warned of the dark side of this concept.

In this regard, V. Putin writes: "The concept of "soft power" is increasingly being used - a set of instruments and methods for achieving foreign policy goals without the use of weapons, but with the help of information and other levers of action. Unfortunately, these methods are often employed to develop and provoke extremism, separatism, nationalism, manipulation of public opinion, and direct interference in the domestic politics of sovereign states.

It is necessary to clearly separate what is freedom of speech and regular political activity, and where illegal instruments of "soft power" are used. The civilized work of humanitarian and charitable non-governmental organizations, including those that criticize the current government, is to be welcomed. However, the activities of "pseudo-NGOs" and other structures that, with the external support destabilize the situation in certain countries must not be allowed".

After these initiatives of the highest representatives of the government, important documents regulating the use of "soft power" institutions were adopted.

${ }^{7}$ Сергей Лавров, интервью “РГ”.30.10.2008 [Электронный ресурс] // Российская газета. http://rg.ru/2008/10/30/lavrov.html (seen: 09.09.2020).

${ }^{8}$ Путин В. Россия и меняющийся мир [Электронный ресурс] // Московские новости. Режим доступа - http://www.mn.ru/politics/78738 (seen: 09.09.2020) 
The importance and role of public diplomacy in the promotion of Russian interests and the position of the state are described in detail in the Concept of Foreign Policy of the Russian Federation from 2013 and additionally emphasized in the new version of the Concept from 2016. With this document, "soft power" is defined as an indispensable part of modern international politics, and its official definition was introduced.

Specifically, the document states that "within public diplomacy, Russia will strive to ensure an objective perception of itself in the world, develop its own effective means of informational influence on public opinion abroad, ensure the strengthening of the position of the Russian media in the global information space, providing them with necessary state support, and it will actively participate in international cooperation in the information sphere and take the necessary measures to prevent information activities aimed at violating its sovereignty and security". ${ }^{\prime}$

According to the new Concept, "soft power" is "a complex instrument for solving foreign policy tasks, based on the possibilities of civil society, information-communication, humanitarian and other methods and techniques, as an alternative to classical diplomacy".

In the same document, the possible negative sides of the use of "soft power" mechanisms were highlighted: "... strengthening global competition and accumulation of crisis potential leads to the risk of destructive and illegal use of "soft power" and abuse of the concept of human rights due to political pressure on sovereign states, interference in their internal affairs, destabilization of the situation, manipulation of public opinion and awareness, including the financing of humanitarian projects, and projects related to the protection of human rights abroad". The second part of Article 20 of the Concept essentially coincides with the theses from the mentioned Putin's pre-election article "Russia and the changing world". In that paper, he called for a clear distinction between the civilized work of humanitarian and charitable non-governmental organizations and the illegal instruments of "soft power" acting through "pseudo-NGOs", supported from abroad to destabilize the situation in certain countries. The Concept also envisages

${ }^{9}$ Концепция внешней политики Российской Федерации, утвержденная Президентом В. В. Путиным 12 февраля 2013 г. // URL: http://www.mid.ru/ bdomp/ns-osndoc.nsf/info/c32577ca0017434944257b160051bf7f, (seen 04.09.2020) 
improvement of the system of application of "soft power" and sets the tasks for finding optimal forms of activity in that area.

Special attention is devoted to "soft power" instruments, which must be actively used in foreign policy. In a special section, entitled: "Information support of foreign policy activity", the importance of using the means of public diplomacy and information and communication technologies is emphasized. According to the text of this document, these tools should, first of all, contribute to the creation of a positive image of Russia, which corresponds to the authority of its culture, education, science, sports, level of civil society development, as well as participation in assistance programs for developing countries (Article 39), and second, to provide the wider world public with complete and accurate information on the country's attitudes towards major international issues, foreign policy initiatives and actions of the Russian Federation, on the processes and plans of its internal socio-economic development and achievements of Russian culture and science (Article 40).

Formally, the main actors in public diplomacy do not belong to the socalled "foreign policy triad": the Ministry of Foreign Affairs, the Army and the special services, and are not directly connected with the state as a political institution. In other words, most subjects of public diplomacy are not in the public service, although professional diplomats can be involved in the process of promoting the country's humanitarian initiatives. On the contrary, it is very important that diplomatic missions abroad be included in the social life of the receiving country and contribute to the development of cultural ties.

In addition to the cultural attaché who directly deals with these types of cooperation, other diplomats, including the ambassador, can attend scientific symposia and conferences and actively cooperate with media houses and social networks. However, this is just the tip of a huge iceberg called "public diplomacy". Its strength is determined by the quantity and quality of overall humanitarian contacts in all spheres of social life.

As already mentioned, the new Concept, in fact, retains all important provisions related to the necessity of using the "soft power" instruments as part of the basic tasks undertaken to ensure national interests and the realization of strategic national priorities of the Russian Federation. Among the most important activities through which the set tasks should be realized are: 
- comprehensive effective protection of the rights and legitimate interests of Russian citizens and compatriots living abroad on various grounds;

- strengthening the role of Russia in the global humanitarian space, spreading and strengthening the position of the Russian language in the world, popularization of the values of national culture, national historical heritage and cultural identity of the Russian people, the Russian educational system and science and consolidation of the Russian diaspora;

- strengthening the position of the Russian media and mass communication in the global information space and bringing the Russian point of view on international processes to the broadest circles of world society;

- support for the development of constructive dialogue and partnership in the interest of reaching agreement and mutual enrichment of different cultures and civilizations.

The document also emphasizes that the use of the "soft power" instruments is becoming an integral part of modern international politics in solving foreign policy tasks; above all, the possibilities of civil society, information-communication, humanitarian and other methods and technologies, which complement traditional diplomatic methods. ${ }^{10}$

Based on all relevant documents, it can be concluded that there are several important actors in the sphere of "soft power". The most noticeable, according to the results of work and presence in the international community, is Rossotrudnichestvo. Its basic tasks are related to strengthening international ties in the humanitarian sphere, as well as forming a positive image of Russia abroad. The main activities of this organization are: support and spread of the Russian language in the world, popularization of Russian science, culture and education, work with compatriots abroad, and implementation of measures in the field of international cooperation and people's diplomacy. Representative offices of this organization operate in a hundred countries around the world.

Similar functions are performed by several other organizations, such as the Fund "Русский мир" (Russian World), the movement “ Мир без нацизма" (The World without Nazism), the Fund for Support and Protection

${ }^{10}$ Концепция внешней политики Российской Федерации (2016), https://inter affairs.ru/news/show/16503, (seen 09.09.2020). 
of the Rights of Citizens Abroad, the Fund for Cooperation with the Russianspeaking Foreign Press, etc. The newer Russian expert platform in the field of international relations is the international discussion club "Валдај". It is an international intellectual forum where open dialogue between experts, politicians, journalists, and other representatives of various social circles is conducted.

The next important institution is the A.M. Gorchakov Fund, as a nongovernmental organization dealing with the support of public diplomacy, cooperation with other non-governmental organizations in their participation in international activities, as well as the involvement of civil society institutions in foreign policy processes.

As a result of an active effort to ensure Russia's increased presence in the world information system, the international information channel Russia Today was formed.

The main purpose of the activity of this channel is to place the Russian position on the key problems of the world community, as well as to inform the global public opinion about the events in Russia.

The National Security Strategy of the Russian Federation until $2020^{11}$ specifies that in the new conditions, within the framework of international cooperation, Russia should apply multi-vector diplomacy, as well as a pragmatic policy that will enable increased opportunities for the Russian Federation to strengthen its influence on the international scene (Article 9).

To achieve this goal, Russian foreign policy should be active and, at the same time, predictable and open, and should strive to find agreements and common interests with other countries based on bilateral and multilateral mutually beneficial partnerships (Article 89).

If Russia really wants to become practically (not only ideologically and normatively) the main driving factor of integration, especially in the Eurasian space, it must devote far more attention to the application of adequate "soft power" technologies. This, above all, means:

${ }^{11}$ Стратегия национальной безопасности Российской Федерации до 2020 года [Электронный ресурс]//Совет безопасности РФ., http://www.scrf.gov.ru/ documents/99.html, (seen 09.09.2020) 
1. Creating a system of priority information zones. According to the Concept of Russia's Foreign Policy, these are the CIS countries and the "near abroad";

2. Application of the so-called new tactics of presence in the information space. This means, among other things, that the broadcasting of information should not be based only on the activities of Russian PIS (Public Information Services), but also on the engagement of partner information houses on the basis of a well-designed work plan and a signed joint agreement;

3. Raising the "quality" of information activities with the aim of "conquering" the audience in conditions of very fierce competition in the information market;

4. Diversification of program contents in terms of their adaptation to the different (target) groups, i.e., audience segments. An illustrative example in this regard is the programs of Western PIS aimed at extending their own goals towards the female population in the Middle East. These activities were especially fruitful in Egypt and Libya. The "liberated" woman became one of the most important subjects and participants in the "revolutionary" events of 2011.

However, as pointed out above, the use of "soft power" systems can have different directions. If the goal of Western countries was to destroy traditional Islamic societies, Russia, in the process of Eurasian integration, must use this resource in an integrative and stabilizing direction.

5. Regular application of the methodology for assessing the effectiveness of the program to monitor the size of the audience and the most important and useful content in order to make appropriate corrections and shift the focus;

6. Cross (mutual) advertising of programmes that are informative and important for the image. For example, regional stations advertise the Russian media and vice versa. Media monitoring in the CIS countries indicates the need for a greater Russian presence in the information space of the region. A special problem is the former positions have been largely lost, and the media market is flooded with competitors. In order to return to the information space of the near and far abroad, it is 
necessary to ensure the media toolkit becomes a true integration resource of Russia. ${ }^{12}$

Without diminishing the importance of traditional PIS, it is necessary to keep in mind that the largest part of the youth audience expects an interactive role in the media. This part of society is important for all holders of "soft power" because working with young people is considered "investing in the future". In the example of Russia, there is another additional motive in that regard, and that is the effort not to allow a complete cessation of its influence in countries that were once together. In that sense, the focus of information activities must be transferred to various forms of Internet journalism. It is especially important all these resources are used not only in Russian but also in the languages of the target audience. Within the process of building the image of the country, it is very important to use bright positive examples of athletes, actors, and artists with whom one can always find a positive correlation with regard to life in a once common state.

In the era of information technology, the use of social networks becomes the basis for building the country's image as well as the realization of other political and social goals. The analysis of the work of social networks enables the formation of a kind of hierarchy, both in terms of the degree of influence on the audience, and in terms of technological applicability. Based on that, the appropriate strategy and methodology of information performance are defined.

The phenomenon of the human self-organization through interaction in the virtual sphere has been well elaborated by the American sociologist Howard Rheingold. In ten years, Rheingold believes, all the main centres where people live will be equipped with numerous interconnected microcircuits. This means an immediate and uninterrupted connection will be provided between individuals and groups around the world. In this way, the formation of a "smart crowd" whose ability to communicate surpasses all previous forms of communication will occur. ${ }^{13}$

${ }^{12}$ Елена Арляпова, Сербия и ЕАЭС: партнерство на расстоянии, Экономические стратегии, Москва, № 5-6, 2015,стр. 2-11.

${ }^{13}$ Говард Рейнгольд, Умная толпа: новая социальная револющия, (превод с енгл. А. Гарькавой), Торговый дом ГРАНД : Фаир пресс, Москва, 2006. 
In his famous book, the trilogy: "The Information Age: Economics, Society and Culture", Manuel Castells analyses the transformation of power relations in the context of new communication circumstances. ${ }^{14}$ The fact is that the Internet, the activity of social networks, and blogging have fundamentally changed the relations within the political processes and overall social relations.

The modern era, according to Castells, is characterized by the so-called IT mode of production in which the basic source of productivity is the technology of generating knowledge, information processing, and symbolic communications. Such production corresponds to globalization, decentralization, and the transition from large economic giants to a flexible network structure of enterprises. It corresponds to the social practice that gives birth to the activity of the social network-based society. Contemporary culture, as part of society, is becoming a "culture of real virtuality", strictly determined by global interactive electronic communication systems by which reality is completely captured and replaced by a virtual expression displayed on the screen. This imaginary and presented world assimilates all special forms, expressions and specifics, and forms its own structure and logic. The primary purpose of the fight in these new conditions, according to the author, is to fight for involvement and participation in the creation of that new integrated communication system. In this system, there are different levels of "information government", at the top of which, for now, is the United States. Analysing the practice in a large area and the most important countries in the world, he, along with a very critical analysis of the period of "Yeltsin's Russia", does not deny the possibility of modern Russia to find its significant (adequate) place in the world of a new social reality. ${ }^{15}$

After all, what we presently call "soft power" was extremely present in the USSR. Even the creator of the concept of "soft power" pointed to the significant presence of these instruments:

"The Soviet Union has also spent billions on active public diplomacy programs that included promoting its high culture, broadcasting,

${ }^{14}$ Manuel Castells, The Rise of the Network Society, the Information Age: Economy, Society and Culture, Vol. I. Cambridge, MA; Oxford, UK: Blackwell, 1996.

${ }^{15}$ See more in: Мирослав Младеновић, Јелена Пономарева, «Мека моћ» Русије као услов успеха евроазијске интеграције, Српска политичка мисао број 1/2016 год. 23. vol. 51, Београд, УДК 327::911.3(497)“19/20“, стр. 11-29; 
spreading misinformation about the West, and sponsoring anti-nuclear protests, peacekeeping missions, and youth organizations".16

In an effort to become a significant subject of international relations again and analogous to real overall potentials to become an active integrating force in the Eurasian space, Russia must pay more attention to the activation of "soft power" resources. It is, at the same time, a necessary condition and the element of its integration potential, but also a significant barrier against various disintegration actions of other countries directed against it. One possibility is to base the cooperation with other countries not only on relations with the authorities of partner countries but also with their civil society.

\section{Russia's “soft power"}

If we talk about the current state of "soft power" of Russia, we must conclude it is not at an enviable level. According to numerous analyses and rankings of countries on this basis, with all the restrictions on the relativity of such actions, we can see that its position is quite low. According to the rating of Softpower30, Russia ranks 26 th. ${ }^{17}$ In contrast, according to the rating of Elcano's Global Presence Report 2017 Soft presence, the Russian Federation is in seventh place out of a total of $80 .{ }^{18}$ According to the methodology of Monocle's Soft Power Survey 2016/17, Russia is not on the list of 25 countries. ${ }^{19}$ Undoubtedly, the difference in the method of assessment conditioned such positions of Russia on different lists. However, in order to relativise this problem and look more realistically at the place of Russian "soft power" in the world, the table below shows the comparative position of Russia, the United States, France, and the People's Republic of China.

${ }^{16}$ (Joseph Nye, Soft Power, Public Affairs, New York, 2004, p.73)

${ }^{17}$ Portland soft power 30 // http://softpower30.portland-communications.com (seen: 10.09.2020)

${ }^{18}$ Elkano's Global Presence Report 2017 // http://www.realinstitutoelcano.org (seen: 10.09.2020)

${ }^{19}$ Soft Power Survey 2016/17 // https://monocle.com. (seen: 10.09.2020) 


\begin{tabular}{|l|c|c|c|}
\hline \multicolumn{1}{|c|}{ Country } & $\begin{array}{c}\text { Portland } \\
\text { Softpower } \\
\text { (30 places) }\end{array}$ & $\begin{array}{c}\text { Monocle`s Soft } \\
\text { Power Survey } \\
\text { (25 places) }\end{array}$ & $\begin{array}{c}\text { Elcano`s Global } \\
\text { Presence } \\
\text { (80 places) }\end{array}$ \\
\hline Russian Federation & 26 & (not in first 25) & 7 \\
\hline USA & 2 & 1 & 1 \\
\hline France & 1 & 5 & 5 \\
\hline PR China & 25 & 20 & 2 \\
\hline
\end{tabular}

The Table is based on the idea of: Виктор Володин, Лилия Рожкова, Ольга Сальникова, «Мягкая сила» в Мировом сообществе и внешней политике России, М: Право и управление. XXI век, №3(44)/2017.

Also, the analysis of the very elements of Russia's "soft power", their condition, and real influence indicate that there is still a lot of room for the practical realization of latent possibilities in that area.

Components of Russia's "soft power"

\begin{tabular}{|l|l|}
\hline ELEMENTS OF "SOFT POWER" & ITS INFLUENCE \\
\hline 1. Export reputation & $\begin{array}{l}\text { Low in most markets, } \\
\text { although there are exceptions }\end{array}$ \\
\hline 2. Reputation of state governing & Low, and this trand continues \\
\hline 3. The quality of the human factor & Ambivalent \\
\hline 4. Tourism development & Low \\
\hline 5. Innovation and immigration & $\begin{array}{l}\text { Attractive for some CIS countries } \\
\text { and countries of the "global south" }\end{array}$ \\
\hline 6. Historical past & Rather big \\
\hline 7. Culture & $\begin{array}{l}\text { Elitist: high impact, but fragmented; } \\
\text { Mass: non-competitive with some exceptions }\end{array}$ \\
\hline 8. Business conditions & Complex with great risks \\
\hline 9. Popularity of media production & Decreased abroad compared to the USSR \\
\hline 10. Language prevalence & $\begin{array}{l}\text { Stable, in areas of demand } \\
\text { for the Russian language; downward trend } \\
\text { (exceptions some neighboring countries) }\end{array}$ \\
\hline
\end{tabular}




\begin{tabular}{|c|c|}
\hline 11. Attitude towards foreign policy & $\begin{array}{l}\text { Complex and changeable, depending } \\
\text { on the changes in the policy itself }\end{array}$ \\
\hline 12. Development of science & $\begin{array}{l}\text { Acceptance and realistic picture } \\
\text { - contradictory }\end{array}$ \\
\hline $\begin{array}{l}\text { 13. Reputation of highly } \\
\text { professional services: } \\
\text { - education, } \\
\text { - medicine, } \\
\text { - finance, } \\
\text { - law, }\end{array}$ & $\begin{array}{l}\text { - The downward trend; } \\
\text { - Not so high; } \\
\text { - Not so high; } \\
\text { - Low }\end{array}$ \\
\hline
\end{tabular}

Source: Виктор Володин, Лилия Рожкова, Ольга Сальникова, «Мягкая сила» в Мировом сообществе и внешней политике России, М: Право и управление. XXI век, №3(44)/2017.

In essence, these indicators show that Russia has not used its potentials enough. Its possibilities to become a significant factor in the application of "soft power" in international relations are based not solely on the geoclimatic distribution, huge natural and human resources, and intellectual potential of citizens but also on culture, tradition, and vast historical experience. ${ }^{20}$

The heroic defence in the Second World War and the decisive contribution to the defeat of fascism and Nazism, as well as the subsequent support for decolonization, have strongly strengthened the prestige, reputation, and soft power of the USSR. Despite the beginning of the Cold War and the rapid change in the image of the USSR in the Western media, the popularity of the communist leader did not decline too much because America, and not the USSR, dropped two nuclear bombs on Japan. To the prestige of the USSR even contributed the change at the head of the CP and the arrival of Khrushchev, who, to some extent, opened the country and started some kind of reforms. The culmination of the growth of the soft power of the Soviets was sending the first satellite and especially the first man into space. In the fifties and sixties, the USSR was well ahead of America in space programs, which, with the continuation of rapid development, was

${ }^{20}$ See more in: Мирослав Младеновић, Јелена Пономарева, Кина-Америка-Русија - глобални троугао 21. века, Социолошки преглед, Београд, бр. 4, вол. 45, 2011, стр. 459-476. 
regarded in the world as a kind of confirmation that the USSR (or communism) was a technologically more advanced and "progressive" side in the conflict. ${ }^{21}$

\section{Russia and the Balkans}

Based on the most important documents regulating the classical and even public foreign policy activities of the Russian Federation, including the use of "soft power", it follows that the Balkans, as well as Serbia, do not belong to its priorities. Despite that, history confirms the Balkans was and remained a special geopolitical and geoeconomic zone for Russia, in which the interests of practically all major subjects of international relations still clash today. The fact is that, despite the collapse of bipolarism, the struggle for influence in various parts of the world is not weakening, but, on the contrary, it is "accompanied by increased turbulence at the global and regional level".

Growing competition in the political, economic and information spheres requires Russia to make serious efforts to maintain its influence in the region and seek effective methods of foreign policy. This, among other things, implies the diversification of communications with different social segments of the Balkan countries, which is impossible without the use of public diplomacy instruments and the elements of "soft power". 22

Certainly, all theoretical considerations and normative assumptions about public diplomacy would not make sense if there were no concrete activities in that domain. Within a large number of NGOs committed to improving Russia's image in the Balkans, the most active institutions are, however, Rossotrudnichestvo, Russian World, and the Gorchakov Fund. Even an extremely superficial analysis may show that this is insufficient to ensure serious competition with the appropriate institutions of Western provenance.

${ }^{21}$ Миша Ђурковић, Русија и откривање меке моћи, Национални интерес, Година IV, vol. 4, Број 1-3/2008. стр. 25-54

${ }^{22}$ See more in: Елена Пономарева, Балканский вектор российской энергодипломатии, Геополитика, Февраль 5th, 2013 | http://www.geopolitics.ru/ 2013/02/balkanskij-vektor-rossijskoj-energodiplomatii/(seen: 10.09.2020) 
Undoubtedly, there are possibilities for Russia to assume a more worthy position in the world again. Whether the respective potentials will be translated into practical solutions depends on a large number of factors, mostly on the ability of the forces that steer Russian society to coordinate joint action on the path of revitalizing the state as one of the most influential subjects in the modern international community.

\section{References}

Елена Арляпова, Сербия и ЕАЭС: партнерство на расстоянии, Экономические стратегии, Москва, № 5-6, 2015, стр. 2-11.

Елена Пономарева, Мирослав Младенович, Публичная дипломатия

России: балканское направление, Международная жизнь апрель 2016, Москва, ISSN 0130-9625, стр. 151-166.

Елена Пономарева, Балканский вектор российской энергодипломатии, Геополитика, Февраль 5th, 2013 | http://www.geopolitics.ru/2013/02/ balkanskij-vektor-rossijskoj-energodiplomatii/

Elkano's Global Presence Report 2017 // http://www.realinstituto elcano.org Фонд поддержки публичной дипломатии им. А.М.Горчакова // URL: http://gorchakovfund.ru/about/

Говард Рейнгольд, Умная толпа: новая социальная революция, (превод с енгл. А. Гарькавой), Торговый дом ГРАНД : Фаир пресс, Москва, 2006.

Joseph Nye, Soft Power, Public Affairs, New York, 2004.

Концепция внешней политики Российской Федерации, утвержденная

Президентом В. В. Путиным 12 февраля 2013 г. // URL: http://www.mid.ru/bdomp/ns-osndoc.nsf/info/c32577ca00174349 44257b160051bf7f

Концепция внешней политики Российской Федерации (2016) https://interaffairs.ru/news/show/16503;

Manuel Castells, The Rise of the Network Society, the Information Age: Economy, Society and Culture, Vol. I. Cambridge, MA; Oxford, UK: Blackwell, 1996. 
Мирослав Младеновић, Јелена Пономарева, Теорија и пракса "шарених револуција", Социолошки преглед, Београд, RS ISSN 0085-6320, UDK 316, 2012, вол. 46, бр. 4, стр. 513-533.

Мирослав Младеновић, Јелена Пономарева, «Мека моћ» Русије - као услов успеха евроазијске интеграције, Српска политичка мисао број 1/2016 год. 23. vol. 51, Београд, УДК 327::911.3(497)“19/20“, стр. 11-29.

Мирослав Младеновић, Јелена Пономарева, Кина-Америка-Русија глобални троугао 21. века, Социолошки преглед, Београд, бр. 4, вол. 45, 2011, стр. 459-476.

Миша Ђурковић, Русија и откривање меке моћи, Национални интерес, Година IV, vol. 4, Број 1-3/2008. стр. 25-54.

Portland soft power 30 // http://softpower30.portland-communications.com Сергей Лавров, интервью “РГ”.30.10.2008 [Электронный ресурс] // Российская газета. http://rg.ru/2008/10/30/lavrov.html

Soft Power Survey 2016/17 // https://monocle.com

Стратегия национальной безопасности Российской Федерации до 2020 года [Электронный ресурс]// Совет безопасности РФ., http://www.scrf.gov.ru/documents/99.html

Указ Президента РФ от 7 мая 2012 г. «0 мерах по реализации внешнеполитического курса Российской Федерации»// URL: http://www.kremlin.ru/events/president/news/15256

Виктор Володин, Лилия Рожкова, Ольга Сальникова, «Мягкая сила» в Мировом сообществе и внешней политике России, М: Право и управление. XXI век, №3(44)/2017.

Владимир Путин, Россия и меняющийся мир [Электронный ресурс] // Московские новости. Режим доступа - http://www.mn.ru/ politics/78738 